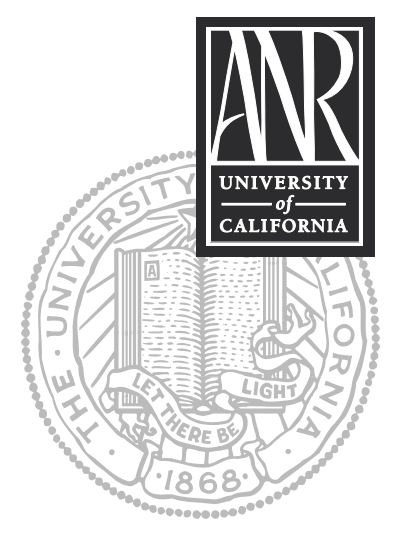

UNIVERSITY OF CALIFORNIA

Division of Agriculture and Natural Resources http://anrcatalog.ucdavis.edu
UC

REVIEWED

\title{
Key Points of Control and Management of Microbial Food Safety: Information for Producers, Handlers, and Processors of Fresh Market Tomatoes
}

TREVOR V. SUSLOW, Extension Research Specialist, Department of Vegetable Crops, University of California, Davis

Most fruits and vegetables eaten fresh in the United States are kept wholesome and free of microorganisms that could result in illness through the use of common and sensible handling and food preparation practices. In addition, many fruits and vegetables have natural barriers that minimize the chances that any surface contamination could be transferred to the internal, edible portions. While not an impervious barrier, the smooth, waxy surface of a tomato has been shown to increase the effectiveness of removal of contamination during washing. Light brush-washing with food-grade disinfectants (such as hypochlorite, chlorine dioxide, ozone, acidified sodium chlorite, or peroxyacetic acid) in combination with food-approved wetting agents largely eliminates surface contamination from globe and roma-type tomatoes. However, research has determined that microbial removal from the stem scar area is particularly difficult to achieve. Of greater concern is the potential for internalization of microbial contaminants during postharvest handling and fresh-cut processing.

Contamination of the tomato's outer surface or internal tissues by microbial pathogens can only result, ultimately, from an external environmental source. Although recent laboratory research has demonstrated the high potential for human pathogens to become internalized into tomatoes, under specific exposure conditions, extensive field surveys of fresh market tomatoes have shown that detectable levels of contamination are very rare. Nonetheless, consumption of fresh tomatoes has been linked to large, multistate outbreaks of foodborne illness at retail and food service outlets as recently as 2002 and 2004. In both of these large outbreaks, Salmonella was identified as the pathogenic agent responsible for illness, and Salmonella was recovered from packaged precut tomatoes at the food service outlet. As with all fruits and vegetables that are eaten uncooked, the best approach to maintaining the wholesome nature and safe consumption of fresh tomatoes is to establish standard approaches to crop management and postharvest handling that minimize the chances of external and internal contamination at every step. The fresh market tomato industry must continue to take a proactive role in delivering this same message to the public in order to assist them in safe food handling and preparation (see also ANR Publication 8116, Tomatoes: Safe Methods to Store, Preserve, and Enjoy).

This publication provides a brief outline of the fundamental components of microbial food safety that should be part of any comprehensive management plan for mature-green and vine-ripe growers, specialty tomato producers, harvest service operators, distribution and wholesale handlers, direct marketers, and fresh-cut processors. The diversity of environments, crop management practices, and handling practices make a single, universally applicable approach to food safety planning unrealistic. Instead, this quick reference guide focuses on the key guiding principles of prevention of contamination, reduction of survival, and prevention of cross-contamination for each step in fresh tomato commerce up to consumer handling. You can create your own food safety planning and management programs through the application of these principles, which are the combined results of specific research and practical experience with diverse tomato management and distribution systems. 
Many of these same principles can be applied to planning for food security and prevention of intentional food contamination. Helpful online resources in counter-bioterrorism planning are listed at the end of this publication.

\section{BACK GROUND}

Whether tomatoes are produced domestically or imported, four key events have brought focus and concern for the microbial food safety of fresh market tomatoes and other edible horticultural foods:

- Recent reoccurring outbreaks of illness linked to consumption of imported and domestic produce.

- Positive detection and recovery of human pathogens from random survey sampling of both imported and domestically produced produce.

- Recent reports from several researchers documenting the difficulty of cleaning and disinfecting produce surfaces.

- Recent reports from several researchers documenting the potential for internalization of pathogens during production and postharvest handling of produce, including tomatoes.

For domestically produced tomatoes, random product surveys conducted by the U.S. Food and Drug Administration during 2001 and 2002 did not result in the positive detection of any targeted pathogens (see FDA Survey of Domestic Fresh Produce 2000/2001, available online at the US FDA Center for Food Safety and Applied Nutrition Web site, http://vm.cfsan.fda.gov/ dms/prodsu10.html). Based on the overall consumption of fresh tomatoes, illness definitively associated with contamination that occurs prior to food preparation is a very low-probability event. It is equally clear, however, that outbreaks linked to tomatoes from various production areas have occurred and that those outbreaks have affected large numbers of individuals across many states and in Canada. While most individuals can recover from foodborne illness without any need for medical attention, patients such as the very young, the very old, and those who may be otherwise immuno-compromised may suffer complications and even death.

\section{WHAT ARE THE GUIDING PRINCIPLES OF FOOD SAFETY FOR FRESH PRODUCE?}

- Once produce has been contaminated, removing or killing pathogens is very difficult.

- Prevention of microbial contamination at all steps from production to distribution is strongly favored over treatments to eliminate contamination after it has occurred.

- Document the implementation of prevention programs and food safety awareness training for workers at all levels of the agricultural and packing environments.

\section{Crop Production Water}

Wherever water comes into contact with fresh produce, the quality of the water may directly determine the potential for persistent pathogen contamination.

- Become familiar with the routes and handling of surface water sources, seasonal influences on water quality, and any microbial monitoring programs followed by the supplier of delivered water from public or private irrigation districts or wastewater reclamation facilities.

- Identify potential sources of contamination that could affect your water, especially those that are within your ability to control in a manner that would protect water quality.

- Ensure that wells are designed and maintained in a manner that prevents surface runoff or soil infiltration from contaminating the water supply. 
- Water used for any foliar applications should come from a pathogen-free source.

- Identify the potential for any foliar spray materials to support the growth of pathogens that might be introduced with source water.

- Until more research data is available, it is strongly recommended that any foliar applications within 2 weeks of harvest be from a potable water source.

\section{Manure and Municipal Biosolids}

Properly composted manures or municipal biosolids are not a source of microbial pathogens on fresh produce.

- Become informed about proper compost management for pathogen reduction and document the methods used to eliminate pathogens from any manure that you apply.

- Document or obtain documentation about the specific compost management for each lot.

- Maximize the time between the date you apply manure to production areas and the date you harvest those areas.

- In any ranch or production block where you use multiseason drip irrigation, pay special attention when spreading chicken manure or litter without incorporating it into the soil to ensure that pathogen reduction practices have been followed and documented.

\section{Minimizing Animal Fecal Contamination}

It is not possible or permissible to eliminate all animal influences from production fields. All the same, you need to determine what steps you can take to minimize their presence and activities.

- Domestic animals should be excluded from tomato fields during the growing and harvesting seasons.

- Evaluate the need for bare soil buffers between your tomato fields and adjacent land. Buffer zones can discourage the movement of reptiles, amphibians, and rodents-all potential sources of contamination-into your fields.

- Minimize the presence of vector attractants (such as cull piles) within a production field.

\section{Worker Health and Hygiene}

There is no substitute for awareness, training, and constant reinforcement of the importance of each worker's personal hygiene and sanitation as critical elements in maintaining a sustainable business for you and continued employment for the worker.

- Follow all OSHA and CAL OSHA requirements for sanitary facilities.

- Establish a training program that includes proper hand washing techniques and the importance of using toilet facilities.

- Establish and communicate a clear policy that allows workers who report or are observed to have symptoms of illness or diarrhea to be reassigned to paid activities that do not involve contact with food or food surfaces. In the absence of such a policy, it is likely that workers will not report their illness for fear that they will lose wages.

- Carefully inspect areas frequented by unsupervised workers (such as night irrigators) for signs that additional training is needed.

- Provide bandages or other protective coverings to workers who have cuts or lesions that may make contact with fresh produce.

- If the workers use gloves, provide instruction on their proper use to prevent pathogen transfer to fresh tomatoes or packing surfaces and packed containers.

- Use caution when servicing portable toilets to prevent leakage into a field.

- Provide physical diversion and containment in the event of waste spillage. Have a plan for how to isolate and destroy contaminated produce in the event of a spill. 


\section{Field and Harvest Sanitation}

All surfaces and implements that touch fresh produce must be treated as food contact surfaces.

- Clean and sanitize all food contact surfaces and harvest containers or bins prior to each use.

- Ensure that harvest contractors and crews are aware of the principles of microbial food safety risk reduction and that they adhere to your established food safety practices.

- Develop and document a system of cleaning and sanitizing food contact surfaces.

- Minimize the opportunity for disease vectors (rodents, birds, flies, reptiles, amphibians, etc.) to contaminate packing surfaces and materials.

- Minimize vectors' access or attraction to harvest equipment kept in the field (for instance, do not leave damaged fruit or heavy juice residues on buckets, belts, in bins, or in trailers and gondolas).

\section{Packing Facilities}

Well-designed and operated centralized packing facilities and packing systems can contribute to the reduction of pathogen contamination. Management lapses in facilities or system management can amplify localized contamination, broadly redistribute pathogens, and create opportunities for pathogen contamination within the facility.

- Design and maintain packing surfaces and equipment to minimize injury to the produce and to maximize accessibility for cleaning and sanitizing.

- Catwalks should prevent dirt or other debris from falling onto dump tanks and flumes, belts, conveyors, and sorting or grading tables.

- Maintain surfaces of bump pads, brush rollers, sponge rollers, and other equipment to minimize microinjury or other damage to fruit. Minor surface microinjuries that would not result in the culling of a tomato have been shown to promote survival of pathogens, especially in combination with fruit waxes.

- Determine the need, frequency, and process for effectively cleaning and sanitizing rollers and brushes.

- Establish routine cleaning and sanitizing programs for all food contact surfaces.

- Remove as much dirt as is practical from harvest containers, trailers, and gondolas between harvest uses. This should be done outside the packing facility, away from any water source used for postharvest handling.

- Clean pallets, containers, or bins before use. The reuse of containers or cartons in a tomato repack operation should be carefully evaluated for any food safety risks.

- Establish and maintain a pest control program.

- Prevent birds or other vectors from contaminating packing equipment surfaces, packing areas, and storage areas.

- Store unformed or empty containers off the floor or bare soil surface and in a way that protects them from contamination.

- Ensure that diluted fruit waxes and sheens do not become contaminated with nonpotable water or by the transfer hose on the packing house floor.

\section{Postharvest Water during Packing}

The quality of postharvest water that contacts fresh produce during postharvest flume transport, cleaning, grading, cooling, and surface treatment application is widely recognized as the essential pathogen control point for fresh produce.

- Follow Good Manufacturing Practices (GMPs) to ensure that all water is of adequate quality throughout all packing operations from start-up to the last packed unit. 
- Antimicrobial chemicals help minimize the potential for microbial contamination to spread in packing operation water. The levels of antimicrobial chemicals must be routinely monitored and recorded to ensure that they stay at appropriate levels.

- Special attention to water quality is required for dump tank systems and recirculated water. In dump and flume systems, maintain chlorinated (or other approved disinfectant) water temperature at least $10^{\circ} \mathrm{F}\left(5.5^{\circ} \mathrm{C}\right)$ warmer than incoming fruit pulp temperature to minimize water infiltration Typically, it is unnecessary to heat water warmer than $104^{\circ} \mathrm{F}\left(40^{\circ} \mathrm{C}\right)$. If chlorinating dump and flume water, at warm temperatures, it is very important to carefully monitor chlorine levels since available antimicrobial activity may be reduced by 15 percent or greater than in water at $68^{\circ} \mathrm{F}\left(20^{\circ} \mathrm{C}\right.$ ). (See also Prevention of Postharvest Water Infiltration into Fresh Market Tomatoes: Food Safety and Spoilage Control Practices accessible at the University of California Cooperative Extension Vegetable Research and Information Web site, http://vric.ucdavis.edu/issues/bulletinboard/tomato_microbial.pdf.)

- Provide a shaded area for incoming fruit in the staging area to minimize heat gain prior to transfer to dump tank or flume.

- Keep air-cooling and chilling equipment clean and sanitary.

\section{Transportation}

Limited control is possible beyond the shipping dock, but the consequences of crosscontamination during transportation and distribution will be linked back to the handler and grower.

- Inspect transportation vehicles for cleanliness, odors, and obvious dirt and debris before loading. If necessary, insist that trailers or containers be cleaned and sanitized before loading.

- Ideally, owner-operators of transport vehicles should have documentation of the prior three loads in the trailer that could be reviewed if there were concerns about chemical or biological contaminants following a loading dock inspection for cleanliness and the presence of unwanted odors.

- Ensure that transporters, distributors, and retailers maintain the integrity of the positive lot identification and trace-back systems that have been implemented by the tomato industry or individual shippers.

\section{Storage and Distribution}

Well-designed and operated wholesale distribution, load consolidation, and crossdocking facilities can maintain the integrity of a pathogen-free product. Lapses in facility sanitation or system management can amplify localized contamination, promote internalization of pathogens into products, and broadly redistribute pathogens.

Mixed storage and mixed-load distribution can transfer contamination from one lot or product to another that was not previously contaminated, especially where palletstacking and mixed loads of wet or iced product are involved.

- Be aware of the potential for cross-contamination.

- Separate dry and wet products and place water-repellant shipping barriers between commodities in mixed loads.

\section{Repack Operations}

Well-designed and operated repack operations and associated facilities can maintain the integrity of a pathogen-free product. Lapses in facility sanitation or system management can amplify localized contamination, promote internalization of pathogens into products, and broadly redistribute pathogens. The diversity of handling practices at repack make a single, universally applicable approach to food safety planning unrealistic. Instead, repackers need to follow the same key guiding principles of prevention 
of contamination, reduction of survival, and prevention of cross-contamination to maintain the safety of the product they receive.

- All repack surfaces should be treated as food contact surfaces, and appropriate daily cleaning and sanitizing measures should be implemented and documented.

- If a washing step is included in the repack line, follow recommendations presented in the section "Postharvest Water during Packing," above.

- In California, a carton can be reused only by the original grower or a repacker who is registered with the state. Any repacking of tomatoes into used containers should include a clear statement on the carton that the product was repacked. Adequate documentation of carton reuse should be maintained by the repacker, including any lot co-mingling.

- If repack operations place sorted fruit into the same shipping cartons, assign someone to inspect each carton to ensure that it meets adequate standards for cleanliness and is suitable to transport fresh food.

- Ideally, no lots of tomatoes should ever be mixed, especially from different suppliers. In cases when avoiding comingling is not practical, ample and clear documentation and records should be maintained.

\section{Fresh-cut or Value-added Processing}

Well-designed and operated processing facilities can contribute to the reduction of pathogen contamination. Lapses in facility or system management can amplify localized contamination, broadly redistribute pathogens to the edible fruit, and contaminate pathogen-free tomatoes from within the facility during handling.

Washing in combination with a disinfectant treatment reduces but does not eliminate microbial contamination. Greater microbial reductions are achieved on smooth, waxy produce (such as tomatoes) than on rough-textured or porous products.

Proper temperature management (cold chain control) is important for quality and safety management but cannot be relied upon, alone, to provide sufficient consumer protection from potential foodborne illness.

Optimal short-term distribution temperatures for fresh whole tomatoes, a chilling-sensitive fruit, should be from $50^{\circ}$ to $55^{\circ} \mathrm{F}\left(10^{\circ}\right.$ to $\left.13^{\circ} \mathrm{C}\right)$ for ripened and mature-green tomatoes, respectively (see "Tomato Facts" at the UC Davis Postharvest Technology Research Information Center Web site, http://rics.ucdavis.edu/post harvest2/Produce/ProduceFacts/Veg/tomato.shtml.) Lower temperatures negatively affect the sensory quality of whole tomatoes after a few days, depending on stage of ripeness. Once sliced or diced, storage and distribution temperatures, typically at or below at or below $41^{\circ} \mathrm{F}\left(5^{\circ} \mathrm{C}\right)$, prevent the growth of most foodborne bacterial pathogens (Listeria monocytogenes is one exception), but refrigeration does not eliminate contamination from the product should it be present. With fresh-cut products, lower temperatures to prevent or retard microbial growth overrides concerns for chilling injury.

- Use only good-quality fruit, free of open wounds or defects that may have allowed bacteria to become internalized. Avoid fruit that have visible sunken areas or areas of mold or decay.

- Product flow should be linear; incoming product should not cross paths or be stored next to cleaned or processed product. Ideally, packing areas should be physically separated from receiving and processing areas.

- Worker traffic flow and activities should not move between packing and receiving.

- Develop worker training programs for fruit handling and processing to prevent bare-hand or gloved-hand contact of uncleaned fruit and cut fruit flesh, in sequence, by the same individual. 
- Antimicrobial chemicals help minimize the potential for microbial contamination to be spread by process water. Levels of antimicrobial chemicals must be routinely monitored and recorded to ensure that they are maintained at appropriate levels.

- Special attention to water quality is required for common wash tank or flume systems and any recirculated water.

\section{RESOURCES FOR UNDERSTANDING AND MINIMIZING MICROBIAL RISKS TO FRESH PRODUCE}

\section{Production and Postharvest}

Food Safety Begins on the Farm Brochure (English and Spanish), 2004, Cornell University Good Agricultural Practices Web site, http://www.gaps.cornell.edu.

On-Farm Food Safety Self Audit and Resource CD-ROM, order from University of California Cooperative Extension Good Agricultural Practices Web site, http:// ucgaps.ucdavis.edu/Information\%5Favailable\%5Fon\%5Fa\%5FCD/.

\section{Overview of Good Agricultural Practices}

Final Guidance: Guide to Minimize Microbial Food Safety Hazards for Fresh Fruits and Vegetables, US FDA Center for Disease Control and Prevention Web site, http://www.foodsafety.gov/ dms/prodguid.html.

\section{System-wide Biosecurity}

Food Security Guidance, Federal Register Notice of Availability, 2002, US FDA Center for Food Safety and Applied Nutrition Web site, http://www.cfsan.fda.gov/ lrd/fr020109.html.

Guidance for Industry: Food Producers, Processors, Transporters and Retailers: Food Security Preventive Measurers Guidance, 2002, US FDA Center for Food Safety and Applied Nutrition Web site, http://www.cfsan.fda.gov/ dms/secguid.html.

Guidance for Industry: Importers and Filers: Food Security Preventive Measures Guidance, 2002, US FDA Center for Food Safety and Applied Nutrition Web site, http://www.cfsan.fda.gov/ dms/secguid2.html.

\section{General Food Safety}

FDA Survey of Domestic Fresh Produce 2000/2001, US FDA Center for Food Safety and Applied Nutrition Web site, http://vm.cfsan.fda.gov/ dms/prodsul0.html.

Prevention of Postharvest Water Infiltration into Fresh Market Tomatoes: Food Safety and Spoilage Control Practices, 1998, University of California Cooperative Extension Vegetable Research and Information Web site, http://vric.ucdavis.edu/issues/bulletinboard/tomato_microbial.pdf.

Tomato Facts, University of California, Davis, Postharvest Technology Research Information Center Web site, http://rics.ucdavis.edu/postharvest2/Produce/ ProduceFacts/Veg/tomato.shtml.

Tomatoes: Safe Methods to Store, Preserve, and Enjoy, ANR Publication 8116, 2004, UC ANR Communication Services Web site, http://anrcatalog.ucdavis.edu 
To order or obtain printed publications and other products, visit the ANR Communication Services online catalog at http://anrcatalog.ucdavis.edu. You can also place orders by mail, phone, or FAX, or request a printed catalog of our products from:

University of California

Agriculture and Natural Resources

Communication Services

6701 San Pablo Avenue, 2nd Floor

Oakland, California 94608-1239

Telephone: (800) 994-8849 or (510) 642-2431; FAX: (510) 643-5470

E-mail inquiries: danrcs@ucdavis.edu

An electronic version of this publication is available on the ANR Communication Services Web site at http://anrcatalog.ucdavis.edu.

\section{Publication 8150}

Partial support for the production and distribution of this brochure is contributed by the National Good Agricultural Practices Training Program (USDA CSREES Agreement \# 99-41560-0821), Tri-State Consortium for Improving Produce Safety (USDA CSREES 00-52102-9637), and the California Tomato Commission.

The information contained in this publication should not be viewed as an authoritative source for current registration status or legal use recommendations of any product. For more information, contact the California Department of Pesticide Regulation Information Center at (916) 324-0399.

(c) 2004 by the Regents of the University of California, Division of Agriculture and Natural Resources. All rights reserved.

The University of California prohibits discrimination or harassment of any person on the basis of race, color, national origin, religion, sex, gender identity, pregnancy (including childbirth, and medical conditions related to pregnancy or childbirth), physical or mental disability, medical condition (cancer-related or genetic characteristics), ancestry, marital status, age, sexual orientation, citizenship, or status as a covered veteran (covered veterans are special disabled veterans, recently separated veterans, Vietnam era veterans, or any other veterans who served on active duty during a war or in a campaign or expedition for which a campaign badge has been authorized) in any of its programs or activities. University policy is intended to be consistent with the provisions of applicable State and Federal laws.

Inquiries regarding the University's nondiscrimination policies may be directed to the Affirmative Action/Staff Personnel Services Director, University of California, Agriculture and Natural Resources, 300 Lakeside Drive, 6th Floor, Oakland, CA 94612-3550 (510) 987-0096. For a free catalog of publications, call (800) 994-8849. For help downloading this publication, call (530) 754-5112.

This publication has been anonymously peer reviewed for technical accuracy by University of California scientists and other qualified professionals. This review process was managed by the ANR Associate Editor for Vegetable Crops. 